\title{
May the analysis of 1918 influenza pandemic give hints to imagine the possible magnitude of Corona Virus Disease-2019 (COVID-19)?
}

\author{
Raffaele Scarpa ${ }^{*}$ (D), Francesco Caso ${ }^{1}$, Luisa Costa ${ }^{1}$, Saverio Passavanti ${ }^{1}$, Maria Grazia Vitale ${ }^{2}$, Claudia Trojaniello ${ }^{2}$,
} Antonio Del Puente ${ }^{1}$ and Paolo A. Ascierto²

\begin{abstract}
Background: In 1918 an unknown infectious agent spread around the world infecting over one-third of the general population and killing almost 50 million people. Many countries were at war, the First World War. Since Spain was a neutral country and Spanish press could report about the infection without censorship, this condition is commonly remembered as "Spanish influenza". This review examines several aspects during the 1918 influenza pandemic to bring out evidences which might be useful to imagine the possible magnitude of the present coronavirus disease 2019 (COVID-19).
\end{abstract}

Methods: In the first part of this review we will examine the origin of the SARS-Coronavirus-2 and 1918 Spanish Influenza Virus and the role played by host and environment in its diffusion. We will also include in our analysis an evaluation of different approaches utilized to restrain the spread of pandemic and to treat infected patients. In the second part, we will try to imagine the magnitude of the present COVID-19 pandemic and the possible measures able to restrain in the present environment its spread.

Results: Several factors characterize the outcome in a viral pandemic infection. They include the complete knowledge of the virus, the complete knowledge of the host and of the environment where the host lives and the pandemic develops.

Conclusion: By comparing the situation seen in 1918 with the current one, we are now in a more favourable position. The experience of the past teaches us that their success is linked to a rapid, constant and lasting application. Then, rather than coercion, awareness of the need to observe such prevention measures works better.

Keywords: COVID-19, Immune response, JAK-inhibitors, Monoclonal antibodies, Passive antibody administration, SARS-CoV-2, Spanish influenza, Antiviral therapy, Biologics, Vaccines

\section{Background}

In 1918, an unknown infectious agent spread around the world infecting over one-third of the general population and killing almost 50 million people. Many countries were at war, the First World War. Since Spain was a

\footnotetext{
*Correspondence: rscarpa@unina.it

${ }^{1}$ Rheumatology Unit, Department of Clinical Medicine and Surgery, University of Naples Federico II, Via Sergio, Pansini 5, 80131 Naples, Italy Full list of author information is available at the end of the article
}

neutral country and Spanish press could report about the infection without censorship, this condition is commonly remembered as "Spanish influenza". Instead, it has been widely recognized that the infection started in the United States of America (USA), in military camps of the Kansas, spreading later in Europe and in the rest of the world after the arrival of American troops in France [1-3].

In the first part of this review we will examine the origin of the virus and the role played by host and environment in its diffusion. We will also include in our analysis 
an evaluation of different approaches utilized to restrain the spread of pandemic and to treat infected patients.

In the second part, we will try to imagine the magnitude of the present COVID-19 pandemic and the possible measures able to restrain in the present environment its spread.

\section{Influenza pandemic}

The recent work by Short and coworkers well highlights several aspects about the origin of the 1918 Influenza Pandemic. There is definite evidence that 1918 influenza pandemic started in the USA, then it spread to Europe and also to the rest of the World, with the movements of American troops [1, 2]. The first American outbreak of 1918 influenza pandemic is usually reported at Camp Funston, an Army training camp located at Fort Riley, southwest of Manhattan in Kansas. However, in late January and early February in Haskell County, in the state of Texas, at three hundred miles west of Funston, a particularly aggressive influenza had been already observed [3]. In fact, local press reported about many people hit by the influenza epidemic, some progressing to pneumonia with several cases of death. We may assume that, because young people of Haskell had moved to Camp Funston for their military training, the outbreak exploded there, on March 1918, probably originated from that previously observed in Haskell. In a few weeks, several soldiers required hospitalization with treatment at the infirmaries scattered around the Army camp. Funston was a critical base for the American troop movements to other military camps and to Europe. Therefore, we may suppose that this was the road for the diffusion of the Influenza pandemic in other American Army bases and later on in France, particularly at Brest, the largest port of disembarkation for American soldiers in Europe [1-3].

The virus sustaining the 1918 Influenza pandemic was a type A, H1N1 subtype strain. Taubenberger and colleagues sequenced the entire 8-segment genome of the 1918 influenza virus, using RNA fragments recovered from the lungs of several victims. Sequence analysis suggests that the ultimate ancestral source of this virus is almost certainly avian $[4,5]$. At least 2 different H1N1 influenza-virus strains circulated simultaneously in 1918. They had markedly different receptor-binding specificities (the first only for human/mammalian cells, the second for both mammalian and avian cells) and both were fatal to humans $[6,7]$. At that time, when pandemic arrived, seasonal influenza viruses were not yet known. In fact their existence was demonstrated only in 1933 [7]. On the other hand, the discovery of the viral agent sustaining 1918 influenza pandemic was possible only in the late 1990s, when the viral genetic material was isolated from victims buried in Alaska permafrost $[8,9]$.
In addition, also original animal reservoir of the 1918 influenza virus remains still controversial. Two hypotheses have been advanced to explain the introduction of the virus in the human population. The first of these supposes a direct introduction from a single unidentified host [5]. The second sustained that 1918 Influenza virus originated from a reassortment process between avian, swine and/or human Influenza viruses in the years prior to the 1918 pandemic [10]. The absence of Influenza virus sequence data prior 1918 pandemic, leaves this question unanswered. In addition, 1918 influenza pandemic spread in three consecutive waves occurring in the 1918 spring, in the 1918 autumn (the worst) and in the 19181919 winter. Analysing the mutations in Haemagglutinins (HA) sequences of viruses circulating in the spring and in the autumn waves, an increased mutation of the HA sequences has been found in the virus sustaining the second. This phenomenon dramatically increased the ability of virus to binding the human receptors of the cells of the respiratory tract [1].

\section{The role played by the host}

The importance of the role played by the host in 1918 influenza pandemic is supported by the different outcomes that infection had both within and among different populations. Several individual aspects sustain this idea. The most important include the age of infected subjects, their humoral and cellular immune response and their metabolic profile. Our review will analyse these points.

Usually, in influenza pandemic older subjects are at increased risk of developing fatal outcome. In 1918 instead young adults exhibited a high mortality rate. This point is still not fully clarified, although problems related to the immune status of the host are supposed [1].

In 1918 influenza pandemic, subjects born before 1889 (aged 30-60 years) showed a better outcome when compared to younger people [11]. This intriguing response may be probably explained by the fact that older subjects had acquired cross-protective antibodies having met in their life an $\mathrm{H} 1$ and/or N1 influenza virus and surely, in the period of time from 1889 to 1892 , the H3 influenza virus which sustained the Russian Influenza pandemic [12]. In contrast, younger people born after 1889 were more immunologically naïve to influenza viruses. This aspect could have determined the lack of pre-existing cross-reactive antibodies, contributing to the high attack rate and the rapid spread of virus in the lower age groups. In addition, the immunologic vulnerability of young people may be also explained with a possible deficiency of cellular immunity determined by a defective response of CD8 + Tcells. This could be related to measles epidemics which were frequently described in the American 
military camps in the winter of 1917-1918. Young people infected by measles before 1918 were more susceptible to a severe influenza during 1918 pandemic $[1,13]$.

Malnutrition may reduce the immune response of the host to influenza viruses. Another related subject may be represented by famine which may increase the severity of all infections and also of influenza. In fact, high mortality rates in India during 1918 pandemic confirm this hypothesis [14]. On the other hand, overweight and particularly obesity may impair humoral and cellular immunity. A clear association between obesity and poor outcome in viral respiratory infections, such as influenza A (H1N1) infection has been reported. This point has been demonstrated in obese subjects who show a defective response of $\mathrm{CD} 8+\mathrm{T}$ cells or a reduced production of antibodies after the seasonal influenza vaccine [15].

Further, in obese subjects, White Adipose Tissue (WAT) leads to a chronic inflammatory status due to upregulation of proinflammatory cytokines, with IL- $1 \beta$ and IL- 6 and other adipokines representing main mediators [16].

A possible impact of obesity on inflammatory status and respiratory tract infection prognosis could be due not only to the alteration of pulmonary physiology, but also to a concomitant WAT- mediated pro-inflammatory status [16].

\section{Approaches adopted to limit the spread of influenza virus in 1918 pandemic Maritime quarantine}

During the 1918 influenza pandemic, maritime travels were the most common transport systems for both tourist and commercial purposes. Therefore, several countries adopted quarantine measures on incoming ships to restrain epidemic. These initiatives resulted often of limited value because introduced too late, or because unable to detected subjects infected but asymptomatic. However, in some cases, when correctly and promptly applied, they helped to protect populations from the worst of the pandemic, as in the case of Australia and of American Samoa $[17,18]$.

\section{Measures of social distancing and of individual prevention}

In 1918, most American cities imposed restrictions on person-to-person relationships and schools, churches, theatres and generally common meeting places were closed. In addition, some mass gatherings such as wedding, funerals and conferences were prohibited. These measures resulted particularly effective when adopted early and when maintained for sufficient time. In fact, when relaxed, usually viral spread restarted. Individual prevention measures, including the use of facemasks and the use of hand sanitizers, showed controversial results.
In fact, while the use of facemasks did not produce sure positive effects in the protection against contagion, in contrast, handwashing and the use of hand sanitizers had a clear protective effect. Recent evidence supports the idea that measures of social distancing added to those of individual prevention, introduced at an early phase and prolonged for a long time, showed the best results in the prevention of contagion. San Francisco, Saint Louis, Milwaukee and Kansas City, that prepared the most effective intervention reduced transmission rates by up to $30-50 \%$. In addition, data supported the reduction of high levels of mortality when social distancing was effectively pursued $[19,20]$.

\section{Clinical manifestations}

1918 Influenza pandemic developed through three waves [21]. Although it globally affected many young adults, the initial, the spring wave (March-June 1918), was clinically mild, without significant effects upon general mortality rates. The second, the autumn wave (late August-December 1918), was unbelievably aggressive with an enormous mortality peak in the healthy young adults. It presented with high fever, cyanosis, and pulmonary oedema. Usually, 7-10 days after the onset of symptoms, patients deceased. In a little percentage, death arrived more rapidly, within $72 \mathrm{~h}$ from the onset of symptoms. The third pandemic phase started in January 1919 and was surprisingly less aggressive. Autoptic examinations particularly performed during the second wave, revealed at lung sections two possible scenarios [22]. The first one, the most common, occurred in patients who had lived for many days after the onset of symptoms. It consisted of an acute aggressive diffuse broncho-pneumonitis with images of microvasculitis and tissue necrosis, haemorrhage and oedema, complicated by the presence of bacteria (including streptococcus pneumoniae, streptococcus pyogenes, haemophilus influenzae and staphylococcus aureus). The second, occurring in no more than 15 per cent of the total fatal cases, particularly those who had lived only few days after the onset of pulmonary signs, consisted of a severe and acute respiratory distress-like syndrome (ARDS) with lungs partially collapsed, dark red, relaxed, with pleural surfaces showing extravasations. On section, lungs appeared dark red and wet [22]. Bronchial lymphnodes were enlarged and dark red. These particular aspects were consistent with an aberrant inflammatory response to 1918 influenza pandemic virus. We may imagine an exaggerated release of proinflammatory cytokines mimicking a cytokine release syndrome (CRS) a condition which occurs when white blood cells and macrophages are activated and release inflammatory cytokines which further activate more leukocytes and macrophages [23]. In 1918 influenza pandemic, young 
people, those previously infected by measles, showed a CD8 + Tcell defective response which exposed subjects to the development of an aberrant inflammatory response amplifying the severity of influenza symptoms [13].

\section{The situation today}

Today we are experiencing a pandemic from a new Coronavirus strain emerged in Wuhan, China, at the end of 2019 [24]. This new virus phylogenetically derives from Coronavirus that supports a Severe Acute Respiratory Syndrome (SARS-COV) and caused the outbreak in 2002 [25]. On February 11, 2020 the International Committee on Taxonomy of Viruses named this new virus as Coronavirus SARS CoV-2 [26] and the World Health Organization has named the disease caused by it as coronavirus disease 2019 (COVID-19) [27]. Although Coronaviruses usually sustain common colds, sometimes, when they pass from animal reservoirs to humans, they cause outbreaks $[28,29]$. This is the case of the SARS-COV outbreak in China, in 2002 (reservoir the bats) [28] or the MERS-COV (Middle East Respiratory Syndrome-Coronavirus) outbreak in 2012 (reservoirs dromedary camels and/or bats) [29]. In the case of COVID-2019, several reservoirs have been suspected (bats, snakes, pangolins). Although the infection route of the first case remains unclear, the place where the contagion started has been probably identified in the Huanan Seafood Wholesale Market of Wuhan. COVID-19 likely spread out from China through air travels of possible infected travellers [24]. Although growing evidence sustain that SARSCOV-2 may be transmitted from asymptomatic people or with mild disease [26, 30,31], its mortality rate appears lower than that reported in the case of SARS-COV or MERS-COV pandemics [32-34].

At this point of our investigation it would be interesting to ask which are the differences from our situation today when compared to the one already experienced by the humanity in 1918. Many aspects today are fortunately different since then. In 1918 there were no antibiotics for treating overlapping bacterial infections, there were no anti-inflammatory agents and there was neither the concept of intensive care nor anything that would come close to it in clinical practice. Even more the existence of the viruses was not even known and the knowledge of the molecular pathways of inflammation and proinflammatory molecules, such as cytokines, will only be demonstrated at the end of 1970s. So, by comparing the situation seen in 1918 with the current one, we are now in a more favourable position. COVID-19 could manifest in its most severe form with fever and pneumonia in up to $15 \%$ of COVID-19 cases, leading to Acute Respiratory Distress Syndrome (ARDS) in up to $5 \%$, with a variable mortality rate in the different countries affected by the pandemic.
This ARDS is believed to be caused by a cytokine release syndrome (CRS) and secondary hemophagocytic lymphohistiocytosis (sHLH), already observed in patients with SARS-COV and MERS-COV [35, 36] as well as in autoimmune/autoinflammatory diseases, leukemia and/or oncologic patients receiving Chimeric Antigen Receptor (CAR)-T cell therapy [37]. Both viruses use the Angiotensin-Converting Enzyme-Related Carboxypeptidase (ACE2) receptor to enter cells. This receptor is expressed on cardiopulmonary tissues and hematopoietic cells, particularly monocytes and macrophages [38]. The infection of monocytes, macrophages and dendritic cells by SARS-COV-2 activates and leads to secretion of IL- 6 and other pro-inflammatory cytokines. IL- 6 binds to membrane-bound IL-6 receptor (mIL-6R) in a complex with Glycoprotein 130 (gp130) [39]. Then, Janus Kinases (JAK) and (signal transducer and activator of transcription 3 (STAT3) mediate downstream signal transduction. JAKs mIL-6R is located on immune cells, whereas membrane-bound gp130 is more ubiquitous. Regarding cis signaling, subsequent effects on the acquired immune system (B and T cells) and innate immune system (neutrophils, macrophages and Natural Killer cells) can contribute to CRS. In the case of trans signaling, IL-6 binds to the soluble form of IL-6R (sIL-6R), leading to a complex with a gp130 dimer on potentially all cell surfaces [40]. Activation of the IL-6-sIL-6R-JAK-STAT3 signaling at level of endothelial cells induces a "cytokine storm". Vascular Endothelial Growth Factor (VEGF), monocyte chemoattractant protein-1 (MCP-1), IL-8, additional IL- 6 are also secreted by endothelial cells and E-cadherin expression is reduced [40]. These changes contribute to vascular permeability and leakage and to ARDS hypotension and pulmonary dysfunction pathophysiology. Macrophage Activation Syndrome (MAS) is a hyperinflammatory syndrome characterized by CRS, cytopenia and multiorgan failure in which IL-6 and ferritin level are particularly elevated. MAS is often triggered by severe viral infections but it also verifies in oncologic patients on CAR T cell therapy [41]. Moreover, more recent evidence report that COVID-19 may be also complicated by a coagulopathy linked to a disseminated intravascular coagulation which results in a thrombotic and/or thromboembolic disease [42-44]. We have to consider that the development of thrombotic and thromboembolic disease could be a direct consequence of the systemic inflammatory process (thrombo-inflammation) [45-48]. In particular, it has been demonstrated that elevated IL-17A levels strongly correlates with vascular dysfunction in subjects affected by rheumatoid arthritis [49]. It has also been reported that high IL-17A levels increase, in both mouse and human, platelet activation [50] and modulate, in vivo, arterial thrombus formation [51] through the 
extracellular signal-regulated kinase-2 (ERK-2) signaling pathway [52]. In addition, a recent study reports that IL$17 \mathrm{~A}$ promotes deep vein thrombosis in humans and mice by enhancing platelet activation/aggregation, neutrophil infiltration, and endothelial cell activation [53]. For these reasons, it could be possible that, in COVID-19 patients, IL-17A could potentially promote a pro-thrombotic state in the vascular system. Therefore, it could be useful to measure IL-17A levels in bronchoalveolar lavage fluid (BALF) and plasma/serum samples of moderate and severe COVID-19 patients [54].

\section{Therapeutic options}

Differently from Spanish Influenza period, today, there are available many different therapeutic strategies for the management of COVID-19 patients.

Antiviral therapy provides nucleoside Analogs already approved for treatment of some viral infections (Favipiravir, Ribavirin, Remdesivir) [55-63], and Protease inhibitors (Lopinavir and ritonavir) $[64,65]$.

The two immunomodulatory agents, Chloroquine and hydrossicloroquine have shown in vitro an antiviral activity against SARS, MERS, HIV and Ebola through the inhibition of endosomal acidification [66-69]. After the recent demonstration in vitro of an efficacy also against COVID-19 [56], the two drugs, and particularly hydrossicloroquine showing the most potent antiviral effect, were suggested, alone and in combination with azithromycin, for COVID-19 patients. The use of this agents is still debated. [70, 71].

The treatment in Intensive Care Units (ICU) is reserved to COVID-2019 patients experiencing an aberrant immune response to viral infection resulting in an inflammatory cytokine storm and at risk of lethal outcome. Autoptic evidence have showed alveolar damage with oedema, proteinaceous exudate, focal reactive hyperplasia of pneumocytes with inflammatory infiltration of patchy and multinucleated giant cells $[72,73]$ and massive intravascular thrombosis of vessels of alveolar septi [74]. In ARDS, although steroids at high doses alone or associated to heparin and to antibiotics should represent an effective treatment for lung inflammation, controversial data in the literature seem to call everything into question [75]. In fact, steroids, alongside a definitely effective anti-inflammatory action, inhibit the immune response to the virus thus preventing its effective clearance [76]. In addition, the occurrence of adverse events are widely described at high and prolonged doses [77, 78]. More recently, the randomized control trial RECOVERY showed that Dexamethasone reduced deaths by one-third in ventilated patients (rate ratio 0.65 [95\% confidence interval 0.48 to 0.88 ]; $\mathrm{p}=0.0003$ ) and by one-fifth in other patients receiving oxygen only (0.80 [0.67 to 0.96]; $\mathrm{p}=0.0021$ ). [79].

Therefore, the direct and rapid inhibition of molecules sustaining the inflammatory processes should assure a rapid and more effective stop of cytokine storm [80, 81]. Finally, the performance of different therapies used to treat ICU patients seems to be also depending by the clinical phase when subjects are treated. [82].

Tocilizumab is a humanized monoclonal antibody developed for blocking IL-6 receptors and has proved to be effective and safe in the treatment of patients with rheumatoid arthritis. Since some oncologic patients, when treated with CART-T cells therapies, may develop a CRS which may be stopped by IL-6 blocker, its use has been hypothesized to stop the cytokinic storm seen in COVID-19 patients [83]. Therefore, patients with severe or critical COVID-19 were recruited and given Tocilizumab according to standard treatment in which IL-6R inhibitor is associated to lopinavir, methylprednisolone, symptomatics and oxygen therapy [83]. Temperature of patients returned normal very quickly with a marked improvement of respiratory function and 20 patients, after two weeks were discharged. On March 19, 2020 the Italian Pharmaceutical Agency (AIFA) approved a Phase II trial where Tocilizumab was administered to 330 COVID-19 induced ARDS patients. By preliminary results, tocilizumab seems a promising approach in these severe cases [83].

These data are confirmed by several retrospective series of patients with severe COVID 19 pneumonia treated with tocilizumab. In these case series, tocilizumab showed meaningful activity in reduction of invasive mechanical ventilation and death [84-86]. However, a press release of the randomised, double blind, phase III trial COVACTA, which compared tocilizumab versus a matching placebo combined with standard of care, reported no statistically significant improvement in clinical status of patients with severe COVID 19 pneumonia. [87] In this study, no baseline IL-6 value, CPR and other inflammation markers were reported neither were used to select patients for the treatment. Actually, other two phase III trials EMPACTA and REMDACTA are evaluating the efficacy and safety of tocilizumab in combination with standard of care and in combination with remdesivir (NCT04409262, NCT04372186) [88]. More in general, no biomarkers data (like baseline IL- 6 value, CPR, absolute lymphocyte count [ALC], neutrophil/lymphocyte ratio, ferritin, $\mathrm{LDH}$, etc.) are available from phase II and phase III trials. Biomarkers exploratory analysis was reported in two different retrospective case series with tocilizumab and sarilumab (another anti-IL6 receptor). In these reports, baseline high level of IL-6 and neutrophil/lymphocyte ratio, a rapid decrease in CRP levels, 
and a rapid increase of ALC are related to response to tocilizumab as well as sarilumab. $[89,90]$.

Other promising therapeutic approaches provide IL-1 blockade by anakinra in COVID-19 patients developing ARDS, managed with non-invasive ventilation outside of the ICU [91] and JAK inhibition by Baricitinib [92].

In addition, given the possible role played by IL17 in the pathogenesis of massive intravascular thrombosis, the use of an anti-IL-17A neutralizing monoclonal antibody should be also proposed as a potential strategy [52].

\section{Vaccines}

Vaccines by reducing morbidity and mortality, are the most effective strategy for the prevention of infectious diseases. Although, in the case of Coronavirus, at present, there are not approved vaccines, against COVID19 more projects are ongoing, using various approaches. The spike protein of Coronaviruses is the most important target for the development of a vaccine. Its block interferes with the mechanism through which viral receptors bind to host cells (ACE2, APN and DPP4 receptors). At present several approaches for the development of vaccines are used including techniques for recombinant subunit vaccines, DNA vaccines or mRNA vaccines [93-96].

\section{Recombinant subunit vaccine}

Subunit vaccine incites immune system without the introduction of infectious virus and shows an interesting safety profile [97]. They stimulate in vivo the response of $\mathrm{T}$ cells and the production of high titers of neutralizing antibodies $[98,99]$. Studies are ongoing for the production of subunit vaccines against COVID-19. Preliminary results seem promising [100-102].

\section{DNA vaccine}

DNA vaccine are an innovative approach for preventive or therapeutic purposes. They consist in direct injection of DNA plasmids expressing virus spike which induce the activation of $\mathrm{T}$ cells and stimulate a wide range of immune responses [103]. At present, pre-clinical trials are ongoing for the production of DNA vaccine against COVID-19 [104-106].

\section{mRNA vaccine}

mRNA vaccines contain mRNAs encoding the antigens which were inoculated in the host by vaccination [107, 108]. mRNA vaccines represent an improvement when compared to conventional ones [108]. Their rapid development along with their intrinsic structural characteristics offer useful advantages. At present, a trial using a mRNA vaccine encoding viral spike protein of COVID19 is ongoing [108].

\section{Passive antibody administration}

In the absence of vaccines and/or monoclonal antibodies and/or effective drug therapies for COVID19 patients, the use of plasma/sera of convalescent patients should be considered for providing immediate immunity to susceptible people. In 1918 influenza pandemic this therapeutic approach reduced the mortality of treated patients [109-114]. Recently the FDA ruled that the use of sera of convalescent patients should be routinely admitted only after the demonstration with clinical trials of their safety and efficacy. Therefore, the FDA, while not ruling out the possible use of this therapeutic approach in particularly compromised prognosis cases, has spurred the creation of a panel of experts for the development of an implementation protocol to rationalize the use of passive antibody administration [115].

\section{Monoclonal antibodies}

Neutralizing monoclonal antibodies (mAbs) isolated from memory B cells of convalescent patients may be useful in order to treat SARS-CoV-2 infections due to the possibility of their production on a large scale and due to their therapeutic effectiveness. Infact, mAbs have shown both prophylactic and therapeutic efficacy against other infectious diseases such as HIV, Ebola and MERS [116-118] and their safety and potency in patients have been demonstrated in multiple clinical trials $[119,120]$.

These mAbs acts by binding to the ACE2 receptor on the host cells, which is used by the SARS-CoV2 to gain access to the cell through the spike (S) glycoprotein expressed on its surface [121]. The S1 subunit is responsible for virus attachment and contains the receptor-binding domain (RBD) which directly binds to the ACE2 receptor on the host cell while the S2 subunit mediates membrane fusion [122].

Three $\mathrm{mAbs}$ have been studied with really good results in mice expressing the humanized ACE2 (hACE2) receptor: BD-368-2 and B38 and H4; CB6, on the other hand, has been studied with other excellents results in vivo in rhesus macaque [123-125].

Another mAb against COVID-19, LY-CoV555 by Eli Lilly, has been jsubjected to a randomized, placebo controlled, double-blind, single-dose clinical trial which included 452 COVID-19 patients. Although only a phase II study, the authors concluded that LY-COV555 is both safe and effective in reducing the viral load and the percentage of patients who were hospitalized, compared to the placebo group [126, 127]. 


\section{Measures of public health intervention}

Quarantine has been demonstrated to be effective in 1918 influenza pandemic. In fact, when firmly imposed in Australia, it protected people from the devastating effects of the second wave of 1918 influenza pandemic [17]. In addition, only the strict quarantine imposed by the Governor of the American Samoa prevented there the spread of the 1918 influenza pandemic. In contrast, this did not happen in western Samoa which was overwhelmed by the contagion brought by New Zealand ships [18]. Today maritime navigation is largely replaced by air navigation. This makes easier for pandemics to spread. It is therefore necessary to implement screening measures at airports at arrivals. Routes most at risk of spreading the pandemic should also be identified and information campaigns on the risks of travel for people who have had contacts with positive suspected should be implemented. Intervention strategies for restriction of mass gatherings are also of fundamental importance for the containment of contagion. It has been proved by the utility of lockdown in the Imperial study, in which the research assessed the impact of restrictions in 11 European countries-Austria, Belgium, Denmark, France, Germany, Italy, Norway, Spain, Sweden, Switzerland and the UK-up to the beginning of May. By that time, around 130,000 people had died from coronavirus in those countries. The researchers used disease modelling to predict how many deaths there would have been if lockdown had not happened. And the work comes from the same group that guided the UK's decision to go into lockdown. They estimated 3.2 million people would have died by 4 May if not for measures such as closing businesses and telling people to stay at home. That meant lockdown saved around 3.1 million lives, including 470,000 in the UK, 690,000 in France and 630,000 in Italy [128]. Among these, school closure showed a documented utility. We may remember here the dramatic increase of 2009 influenza pandemic in Mexico when school activities started again [129]. The efficacy of intervention strategies is also dependent by their duration. The facemasks were a credible measure of infection prevention during the 1918 pandemic. Their use was particularly supported by the fact that they counteracted the possible transmission of the infection by air. In several U.S. cities, their use was made mandatory by law, and this provision was supported by pressing information campaigns [130, 131]. Nevertheless, a recent meta-analysis supports physical distancing of $1 \mathrm{~m}$ or more and optimum use of face masks, respirators, and eye protection prevent the spread of the SARS-Cov 2 [129]. Their use is extremely important for medical personal who could be directly exposed to the possible contagion when assisting patients $[132,133]$.

Finally, Spanish influenza teach us of pay close attention to factors contributing to the generation of its multiple waves incidence mainly represented by schools opening and closing, and changes in human behaviour in response to the outbreak [134].

\section{Conclusions}

The experience of the past teaches us that battle against pandemic is linked to a rapid, constant, and lasting application. Fortunately, today, knowledge in medicine, particularly in the field of therapies and vaccination are greatly improved when compared to the last century. This is also the case of most sophisticated laboratory advancement able for example to better characterize genotype host characteristics, such as Human leukocyte antigens (HLAs) polymorphisms, involved often in virus susceptibilities.

HLAs are proteins encoded by a several human genes located in the major histocompatibility complex and recognize infectious stimuli leading to immune defense against infection. These can show heterogenous and differ for ethnicity and geographic distributions. HLA variation affects the cellular immune response to coronaviruses peptides and HLA type of patients affected by COVID-19 has been called in cause in addressing disease severity and clinical outcome [135]. So, by comparing the situation seen in 1918 with the current one, we are now in a more favourable position. Then, rather than coercion, awareness of the need to observe such prevention measures works better. A future mass vaccination campaign against COVID-19, as well other infectious diseases involving administration of vaccine doses to a large population over a short period of time is expected [136]. Very effective for this purpose are information campaigns that sometimes involve well-known figures, especially from the world of entertainment or sports.

The COVID-19 pandemic, which probably is the most dreadful one in the last 100 years after Spanish flu, has posed a difficult challenge for any individual. However, differently from Spanish Influenza, today, more sophisticated measures of Public Health Intervention have led to better strategies for fighting the virus and reducing the impact of negative health social, and economic pandemic effects [137]. At first, the COVID-19 pandemic has addressed the speedy use of multiple approaches acting on pathogenesis of this SARS-COV-2, by immunomodulants, monoclonal antibodies and antivirals drugs. COVID-19 pandemic has urged the scientific experts to find rapidly responses in terms of vaccines to control SARS-CoV-2 [137]. Not casually, COVID-19 represents the only outbreak to date in which in a time of less than 
9 months from pandemic emergence, there has been a mounting development of vaccines [138]. Unfortunately, it remains an imperative request for vaccine development since no effective therapies or vaccines have been approved to date [138]. Further, it is still far too early to know what the best vaccines will be to prevent or minimize COVID-19 and their approval will depend upon the results of the efficacy and safety studies [138]. Of note, today we know that effective interventions to reduce the spread of the virus are represented by more testing, wearing face masks, and social distances [138].

As healthcare systems are very focused on COVID-19 care, the spread of the SARS-COV-2 also carry negative health effects, and an example is represented by limitation of access for chronic and not-surge diseases [139, 140]. Economic effects cannot be separated from health effects, and interventions designed to control COVID-19 need to take account of consequences [141].

It is today clear that as there is a need for rapid, innovative, and cost-effective emergency response mechanisms and the presence of gaps in critical care volume come to be conspicuously evident in most countries worldwide [142]. To respond to the growing demand of ICU beds and ventilators, frameworks for rationing have been developed to ensure the reasonable allocation of scarce resources [143]. Worldwide, the exponential increase in COVID-19 cases and subsequent demand for ICU beds is overcoming the capacity of even the largest hospitals. It is need for this pandemic that Countries maintain measures to strictly control the rate of new cases and continue to improve ICU bed capacity [144]. Additionally to the increase of ICU bed capacity, it is key that national health service provide a large increase in invasive ventilators and clinician and nursing staff numbers [145].

\begin{abstract}
Abbreviations
ACE2: Angiotensin-Converting Enzyme; ARDS: Acute respiratory distress-like syndrome; BALF: Bronchoalveolar lavage fluid; CAR: Chimeric Antigen Receptor; COVID-19: Coronavirus disease 2019; CRS: Cytokine release syndrome; H1N1: Hemagglutinin 1 and Neuraminidase 1 subtype; ICU: Intensive Care Units; IL1: Interleukin-1; IL-6: Interleukin-6; IL-17A: Interleukin-17A; JAKs: Janus Kinases; mAbs: Monoclonal antibodies; MAS: Macrophage Activation Syndrome; MERS-COV: Middle East Respiratory Syndrome-Coronavirus; mIL-6R: Membrane-bound IL-6 receptor; NAK: Numb-associated kinase; SARSCOV-2: Severe Acute Respiratory Syndrome Coronavirus -2; sHLH: Secondary hemophagocytic lymphohistiocytosis; STAT3: Signal transducer and activator of transcription 3; WAT: White Adipose Tissue.
\end{abstract}

\section{Acknowledgements}

Not applicable.

\section{Authors' contributions}

RS, FC, LC and PAA wrote the paper. RS, FC, LC, MGV, CT, ADP and PAA contributed to the final revision of the project. All authors read and approved the final manuscript.

\section{Funding}

No funding was used to conduct this research.

\section{Availability of data and materials}

All data generated or analyzed during this study are included in this published article.

\section{Ethics approval and consent to participate}

Not applicable.

\section{Consent for publication}

Not applicable.

\section{Competing interests}

PAA has/had a consultant/advisory role for Bristol Myers-Squibb, RocheGenentech, Merck Sharp \& Dohme, Array, Novartis, Merck Serono, Pierre Fabre, Incyte, NewLink Genetics, Genmab, Medimmune, AstraZeneca, Syndax, SunPharma, Sanofi, Idera, Ultimovacs, Sandoz, Immunocore, 4SC, Alkermes, Italfarmaco, Nektar, Boehringer-Ingelheim. He also received research funds from Bristol Myers-Squibb, Roche-Genentech, Array, and travel support from MSD. RS, FC, LC, MGV, CT, ADP declare that they have no competing interests.

\section{Author details}

${ }^{1}$ Rheumatology Unit, Department of Clinical Medicine and Surgery, University of Naples Federico II, Via Sergio, Pansini 5, 80131 Naples, Italy. ${ }^{2}$ Department of Melanoma, Cancer Immunotherapy and Development Therapeutics, Istituto Nazionale Tumori IRCCS Fondazione Pascale, Naples, Italy.

Received: 24 September 2020 Accepted: 10 December 2020 Published online: 22 December 2020

References

1. Short KR, Kedzierska K, van de Sandt CE. Back to the future: lessons learned from the 1918 influenza pandemic. Front Cell Infect Microbiol. 2018:8:343.

2. Burnet FM, Clark E. Influenza: a survey of the last fifty years. Melbourne: Macmillan Co.; 1942.

3. Barry JM. The site of origin of the 1918 influenza pandemic and its public health implications. J TransI Med. 2004;2:3.

4. Taubenberger JK, Reid AH, Krafft A, Bijwaard KE, Fanning TG. Initial genetic characterization of the 1918 "Spanish" influenza virus. Science. 1997;275:1793-6.

5. Taubenberger JK, Reid AH, Lourens RM, Wang R, Jin G, Fanning TG, Characterization of the 1918 influenza polymerase genes. Nature. 2005:437:889-93.

6. Glaser L, Stevens J, Zamarin D, Wilson IA, García-Sastre A, Tumpey TM, Basler CF, Taubenberger JK, Palese P. A single amino acid substitution in 1918 influenza virus hemagglutinin changes receptor binding specificity. J Virol. 2005;79:11533-6.

7. Stevens J, Blixt O, Glaser L, Taubenberger JK, Palese P, Paulson JC, Wilson IA. Glycan microarray analysis of the hemagglutinins from modern and pandemic influenza viruses reveals different receptor specificities. J Mol Biol. 2006;355:1143-55.

8. Smith W, Andrewes $\mathrm{CH}$, Laidlaw PP. A virus obtained from influenza patients. Lancet. 1933;222:66-68.

9. Reid AH, Fanning TG, Hultin JV, Taubenberger JK. Origin and evolution of the 1918 "Spanish" influenza virus hemagglutinin gene. Proc Natl Acad Sci USA. 1999;96:1651-6.

10. Smith GJ, Bahl J, Vijaykrishna D, Zhang J, Poon LL, Chen H, Webster RG, Peiris JS, Guan Y. Dating the emergence of pandemic influenza viruses. Proc Natl Acad Sci USA. 2009;106:11709-12.

11. Luk J, Gross P, Thompson WW. Observations on mortality during the 1918 influenza pandemic. Clin Infect Dis. 2001;33:1375-8.

12. Ahmed R, Oldstone MB, Palese P. Protective immunity and susceptibility to infectious diseases: lessons from the 1918 influenza pandemic. Nat Immunol. 2007;8:1188-93.

13. Morens DM, Taubenberger JK. A forgotten epidemic that changed medicine: measles in the US Army, 1917-18. Lancet Infect Dis. 2015;15:852-61.

14. Mills ID. The 1918-1919 influenza pandemic-the Indian experience. Indian Econ Soc Hist Rev. 1986;23:1-40. 
15. Sheridan PA, Paich HA, Handy J, Karlsson EA, Hudgens MG, Sammon AB, Holland LA, Weir S, Noah TL, Beck MA. Obesity is associated with impaired immune response to influenza vaccination in humans. Int J Obes (Lond). 2012;36:1072-7.

16. Caso F, Postiglione L, Covelli B, Ricciardone M, Di Spigna G, Formisano P, D'Esposito V, Girolimetto N, Tasso M, Peluso R, Navarini L, Ciccozzi M, Margiotta DPE, Oliviero F, Afeltra A, Punzi L, Del Puente A, Scarpa $\mathrm{R}$, Costa L. Pro-inflammatory adipokine profile in psoriatic arthritis: results from a cross- sectional study comparing PsA subset with evident cutaneous involvement and subset "sine psoriasis". Clin Rheumatol. 2019;38:2547-52.

17. Crosby AW. America's Forgotten Pandemic: the Influenza of 1918. Cambridge: Cambridge University Press; 2003. https://doi.org/10.1017/ cbo9780511586576.

18. Shanks GD, Brundage JF. Pacific islands which escaped the 1918-1919 influenza pandemic and their subsequent mortality experiences. Epidemiol Infect. 2013;141:353-6.

19. Bootsma MC, Ferguson NM. The effect of public health measures on the 1918 influenza pandemic in US cities. Proc Natl Acad Sci U S A 2007;104:7588-93.

20. Hatchett RJ, Mecher CE, Lipsitch M. Public health interventions and epidemic intensity during the 1918 influenza pandemic. Proc Natl Acad Sci U S A. 2007;104:7582-7.

21. Frost WH. The epidemiology of influenza. Public Health Rep. 2006;121:149-59.

22. Wolbach SB. Comments on the pathology and bacteriology of fatal influenza cases, as observed at Camp Devens, Mass. Johns Hopkins Hospital Bulletin. 1919;30:104-9.

23. Shimabukuro-Vornhagen A, Gödel P, Subklewe M, Stemmler HJ, Schlößer HA, Schlaak M, Kochanek M, Böll B, von Bergwelt-Baildon MS Cytokine release syndrome. J Immunother Cancer. 2018;6:56.

24. Ahn DG, Shin HJ, Kim MH, Lee S, Kim HS, Myoung J, Kim BT, Kim SJ. Current status of epidemiology, diagnosis, therapeutics, and vaccines for novel coronavirus disease 2019 (COVID-19). J Microbiol Biotechnol. 2020:30:313-24

25. Lu R, Zhao X, Li J, Niu P, Yang B, Wu H, Wang W, Song H, Huang B, Zhu N, Bi Y, Ma X, Zhan F, Wang L, Hu T, Zhou H, Hu Z, Zhou W, Zhao L, Chen J, Meng Y, Wang J, Lin Y, Yuan J, Xie Z, Ma J, Liu WJ, Wang D, Xu W, Holmes EC, Gao GF, Wu G, Chen W, Shi W, Tan W. Genomic characterisation and epidemiology of 2019 novel coronavirus: implications for virus origins and receptor binding. Lancet. 2020;395:565-74

26. Pan X, Chen D, Xia Y, Wu X, Li T, Ou X, Zhou L, Liu J. Asymptomatic cases in a family cluster with SARS-CoV-2 infection. Lancet Infect Dis. 2020;20:410-1.

27. https://www.who.int/docs/default-source/coronaviruse/situation-repor ts/20200121-sitrep-1-2019-ncov.pdf?sfvrsn=20a99c10_4. Accessed 17 Jul 2020.

28. Li W, Shi Z, Yu M, Ren W, Smith C, Epstein JH, Wang H, Crameri G, Hu Z, Zhang H, Zhang J, McEachern J, Field H, Daszak P, Eaton BT, Zhang S, Wang LF. Bats are natural reservoirs of SARS-like coronaviruses. Science. 2005;310:676-9.

29. Corman VM, Ithete NL, Richards LR, Schoeman MC, Preiser W, Drosten C, Drexler JF. Rooting the phylogenetic tree of middle East respiratory syndrome coronavirus by characterization of a conspecific virus from an African bat. J Virol. 2014;88:11297-303.

30. Bai Y, Yao L, Wei T, Tian F, Jin DY, Chen L, Wang M. Presumed asymptomatic carrier transmission of COVID-19. JAMA. 2020;21(323):1406-7.

31. Rothe C, Schunk M, Sothmann P, Bretzel G, Froeschl G, Wallrauch C, Zimmer T, Thiel V, Janke C, Guggemos W, Seilmaier M, Drosten C, Vollmar P, Zwirglmaier K, Zange S, Wölfel R, Hoelscher M. Transmission of 2019nCoV Infection from an Asymptomatic Contact in Germany. N Engl J Med. 2020:382:970-1.

32. https://www.who.int/docs/default-source/coronaviruse/who-china -joint-mission-on-covid-19-final-report.pdf. Accessed 17 Jul 2020

33. https://www.who.int/csr/sars/country/table/en/. Accessed 17 Jul 2020.

34. https://www.who.int/emergencies/mers-cov/en/. Accessed $17 \mathrm{Jul}$ 2020

35. Kim ES, Choe PG, Park WB, Oh HS, Kim EJ, Nam EY, Na SH, Kim M, Song $\mathrm{KH}$, Bang JH, Park SW, Kim HB, Kim NJ, Oh MD. Clinical progression and cytokine profiles of middle east respiratory syndrome coronavirus infection. J Korean Med Sci. 2016:31:1717-25.
36. To KF, Chan PK, Chan KF, Lee WK, Lam WY, Wong KF, Tang NL, Tsang DN, Sung RY, Buckley TA, Tam JS, Cheng AF. Pathology of fatal human infection associated with avian influenza A H5N1 virus. J Med Virol. 2001;63:242-6.

37. Moore JB, June $\mathrm{CH}$. Cytokine release syndrome in severe COVID-19. Science. 2020;368:473-4.

38. Yang $X, Y u Y, X u$ J, Shu H, Xia J, Liu H, Wu Y, Zhang L, Yu Z, Fang M, Yu T, Wang Y, Pan S, Zou X, Yuan S, Shang Y. Clinical course and outcomes of critically ill patients with SARS-CoV-2 pneumonia in Wuhan, China: a single-centered, retrospective, observational study. Lancet Respir Med. 2020;8:475-81.

39. Kang S, Tanaka T, Narazaki M, Kishimoto T. Targeting Interleukin-6 Signaling in Clinic. Immunity. 2019;50:1007-23.

40. Tanaka T, Narazaki M, Kishimoto T. Immunotherapeutic implications of IL-6 blockade for cytokine storm. Immunotherapy. 2016;8:959-70.

41. Crayne CB, Albeituni S, Nichols KE, Cron RQ. The immunology of macrophage activation syndrome. Front Immunol. 2019;10:119.

42. Chen N, Zhou M, Dong X, Qu J, Gong F, Han Y, Qiu Y, Wang J, Liu Y, Wei Y, Xia J, Yu T, Zhang X, Zhang L. Epidemiological and clinical characteristics of 99 cases of 2019 novel coronavirus pneumonia in Wuhan, China: a descriptive study. Lancet. 2020;395:507-13.

43. Huang C, Wang Y, Li X, Ren L, Zhao J, Hu Y, Zhang L, Fan G, Xu J, Gu X, Cheng Z, Yu T, Xia J, Wei Y, Wu W, Xie X, Yin W, Li H, Liu M, Xiao Y, Gao H, Xie Guo L. Clinical features of patients infected with, 2019, novel coronavirus in Wuhan, China. Lancet. 2020;395:497-506.

44. Tang N, Li D, Wang X, Sun Z. Abnormal coagulation parameters are associated with poor prognosis in patients with novel coronavirus pneumonia. J Thromb Haemost. 2020;18:844-7.

45. Caso F, Costa L, Ruscitti P, Navarini L, Del Puente A, Giacomelli R, Scarpa R. Could Sars-coronavirus-2 trigger autoimmune and/or autoinflammatory mechanisms in genetically predisposed subjects? Autoimmun Rev. 2020;19:102524

46. McGonagle D, Sharif K, O'Regan A, Bridgewood C. The role of cytokines including Interleukin-6 in COVID-19 induced pneumonia and macrophage activation syndrome-like disease. Autoimmun Rev. 2020;19:102537.

47. Feng Y, Yu M, Zhu F, Zhang S, Ding P, Wang M. IL-9 promotes the development of deep venous thrombosis by facilitating platelet function. Thromb Haemost. 2018;118:1885-94.

48. Casillo GM, Mansour AA, Raucci F, Saviano A, Mascolo N, Iqbal AJ, Maione F. Could IL-17 represent a new therapeutic target for the treatment and/or management of COVID-19-related respiratory syndrome? Pharmacol Res. 2020;156:104791.

49. Marder W, Khalatbari S, Myles JD, Hench R, Yalavarthi S, Lustig S, Brook R, Kaplan MJ. Interleukin 17 as a novel predictor of vascular function in rheumatoid arthritis. Ann Rheum Dis. 2011;70:1550-5.

50. Maione F, Cicala C, Liverani E, Mascolo N, Perretti M, D'Acquisto F. IL-17A increases ADP-induced platelet aggregation. Biochem Biophys Res Commun. 2011:408:658-62.

51. Maione F, Parisi A, Caiazzo E, Morello S, D’Acquisto F, Mascolo N, Cicala C. Interleukin-17A exacerbates ferric chloride-induced arterial thrombosis in rat carotid artery. Int J Inflam. 2014;2014:247503.

52. Zhang S, Yuan J, Yu M, Fan H, Guo ZQ, Yang R, Guo HP, Liao YH, Wang M. IL-17A facilitates platelet function through the ERK2 signaling pathway in patients with acute coronary syndrome. PLoS ONE. 2012;7:e40641.

53. Ding P, Zhang S, Yu M, Feng Y, Long Q, Yang H, Li J, Wang M. IL-17A promotes the formation of deep vein thrombosis in a mouse model. Int Immunopharmacol. 2018;57:132-8.

54. Raucci F, Mansour AA, Casillo GM, Saviano A, Caso F, Scarpa R, Mascolo $\mathrm{N}$, labal AJ, Maione F. Interleukin-17A (IL-17A), a key molecule of innate and adaptive immunity, and its potential involvement in COVID19-related thrombotic and vascular mechanisms. Autoimmun Rev. 2020;19:102572.

55. De Clercq E. New nucleoside analogues for the treatment of hemorrhagic fever virus infections. Chem Asian J. 2019;14:3962-8.

56. Wang M, Cao R, Zhang L, Yang X, Liu J, Xu M, Shi Z, Hu Z, Zhong W, Xiao $G$. Remdesivir and chloroquine effectively inhibit the recently emerged novel coronavirus (2019-nCoV) in vitro. Cell Res. 2020;30:269-71.

57. So LK, Lau AC, Yam LY, Cheung TM, Poon E, Yung RW, Yuen KY. Development of a standard treatment protocol for severe acute respiratory syndrome. Lancet. 2003;361:1615-7. 
58. Al-Tawfiq JA, Momattin H, Dib J, Memish ZA. Ribavirin and interferon therapy in patients infected with the Middle East respiratory syndrome coronavirus: an observational study. Int J Infect Dis. 2014;20:42-6.

59. Zumla A, Chan JF, Azhar El, Hui DS, Yuen KY. Coronaviruses - drug discovery and therapeutic options. Nat Rev Drug Discov. 2016;15:327-47.

60. Choy M. Pharmaceutical Approval Update. PT. 2016;41:416-41.

61. Sheahan TP, Sims AC, Graham RL, Menachery VD, Gralinski LE, Case JB, Leist SR, Pyrc K, Feng JY, Trantcheva I, Bannister R, Park Y, Babusis D, Clarke MO, Mackman RL, Spahn JE, Palmiotti CA, Siegel D, Ray AS, Cihlar T, Jordan R, Denison MR, Baric RS. Broad-spectrum antiviral GS-5734 inhibits both epidemic and zoonotic coronaviruses. Sci Transl Med. 2017:9:3653.

62. Mulangu S, Dodd LE, Davey RT Jr, TshianiMbaya O, Proschan M, Mukadi D, LusakibanzaManzo M, Nzolo D, TshombaOloma A, Ibanda A, Ali R, Coulibaly S, Levine AC, Grais R, Diaz J, Lane HC, Muyembe-Tamfum JJ, Sivahera B, Camara M, Kojan R, Walker R, Dighero-Kemp B, Cao H, Mukumbayi P, Mbala-Kingebeni P, Ahuka S, Albert S, Bonnett T, Crozier I, Duvenhage M, Proffitt C, Teitelbaum M, Moench T, Aboulhab J, Barrett K, Cahill K, Cone K, Eckes R, Hensley L, Herpin B, Higgs E, Ledgerwood J, Pierson J, Smolskis M, Sow Y, Tierney J, Sivapalasingam S, Holman W, Gettinger N, Vallée D, Nordwall J. A randomized, controlled trial of ebola virus disease therapeutics. N Engl J Med. 2019;381:2293-303.

63. Wang Y, Zhang D, Du G, Du R, Zhao J, Jin Y, Fu S, Gao L, Cheng Z, Lu Q, Hu Y, Luo G, Wang K, Lu Y, Li H, Wang S, Ruan S, Yang C, Mei C, Wang Y, Ding D, Wu F, Tang X, Ye X, Ye Y, Liu B, Yang J, Yin W, Wang A, Fan G, Zhou F, Liu Z, Gu X, Xu J, Shang L, Zhang Y, Cao L, Guo T, Wan Y, Qin H, Jiang Y, Jaki T, Hayden FG, Horby PW, Cao B, Wang C. Remdesivir in adults with severe COVID-19: a randomised, double-blind, placebo-controlled, multicentre trial. Lancet. 2020;395:1569-78. https://doi.org/10.1016/ S0140-6736(20)31022-9.

64. Chu CM, Cheng VC, Hung IF, Wong MM, Chan KH, Chan KS, Kao RY, Poon LL, Wong CL, Guan Y, Peiris JS, Yuen KY. Role of lopinavir/ritonavir in the treatment of SARS: initial virological and clinical findings. Thorax. 2004;59:252-6.

65. Chan KS, Lai ST, Chu CM, Tsui E, Tam CY, Wong MM, Tse MW, Que TL, Peiris JS, Sung J, Wong VC, Yuen KY. Treatment of severe acute respiratory syndrome with lopinavir/ritonavir: a multicentre retrospective matched cohort study. Hong Kong Med J. 2003;9:399-406.

66. Kono M, Tatsumi K, Imai AM, Saito K, Kuriyama T, Shirasawa H. Inhibition of human coronavirus 229E infection in human epithelial lung cells (L132) by chloroquine: involvement of p38 MAPK and ERK. Antiviral Res. 2008;77:150-2.

67. Vincent MJ, Bergeron E, Benjannet S, Erickson BR, Rollin PE, KsiazekTG, Seidah NG, Nichol ST. Chloroquine is a potent inhibitor of SARS coronavirus infection and spread. Virol J. 2005;22(2):69.

68. Keyaerts E, Vijgen L, Maes P, Neyts J, Van Ranst M. In vitro inhibition of severe acute respiratory syndrome coronavirus by chloroquine. Biochem Biophys Res Commun. 2004;323:264-8.

69. Savarino A, Boelaert JR, Cassone A, Majori G, Cauda R. Effects of chloroquine on viral infections: an old drug against today's diseases? Lancet Infect. Dis. 2003;3:722-7.

70. Vastarella M, Patrì A, Annunziata MC, Cantelli M, Nappa P, Tasso M, Costa L, Caso F, Fabbrocini G. Can hydroxychloroquine be useful in the prevention of COVID-19? An Italian survey in dermatologic and rheumatologic patients already under treatment. J Am Acad Dermatol. 2020;83:e77-9.

71. Arshad S, Kilgore P, Chaudhry ZS, Jacobsen G, Wang DD, Huitsing K, Brar I, Alangaden GJ, Ramesh MS, McKinnon JE, O'Neill W, Zervos M. Treatment with hydroxychloroquine, azithromycin, and combination in patients hospitalized with COVID-19. Int J Infect Dis. 2020;97:396-403.

72. Tian S, Hu W, Niu L, Liu H, Xu H, Xiao SY. Pulmonary Pathology of EarlyPhase 2019 Novel Coronavirus (COVID-19) Pneumonia in Two Patients With Lung Cancer. J Thorac Oncol. 2020;15:700-4.

73. Xu Z, Shi L, Wang Y, Zhang J, Huang L, Zhang C, Liu S, Zhao P, Liu H, Zhu L, Tai Y, Bai C, Gao T, Song J, Xia P, Dong J, Zhao J, Wang FS. Pathological findings of COVID-19 associated with acute respiratory distress syndrome. Lancet Respir Med. 2020;8:420-2.

74. Luo W, Yu H, Gou J, Li X, Sun Y, Li J, Liu L. Clinical pathology of critical patient with novel coronavirus pneumonia (COVID-19). Preprints 2020, 2020020407.
75. Russell CD, Millar JE, Baillie JK. Clinical evidence does not support corticosteroid treatment for 2019-nCoV lung injury. Lancet. 2020;395:473-5.

76. Arabi YM, Mandourah Y, Al-Hameed F, Sindi AA, Almekhlafi GA, Hussein MA, Jose J, Pinto R, Al-Omari A, Kharaba A, Almotairi A, Al Khatib K, Alraddadi B, Shalhoub S, Abdulmomen A, Qushmaq I, Mady A, Solaiman O, Al-Aithan AM, Al-Raddadi R, Ragab A, Balkhy HH, Al Harthy A, Deeb AM, Al Mutairi H, Al-Dawood A, Merson L, Hayden FG, Fowler RA; Saudi Critical Care Trial Group. Corticosteroid Therapy for Critically III Patients with Middle East Respiratory Syndrome. Am J Respir Crit Care Med. 2018;197:757-767.

77. Lee DT, Wing YK, Leung HC, Sung JJ, Ng YK, Yiu GC, Chen RY, Chiu HF. Factors associated with psychosis among patients with severe acute respiratory syndrome: a case-control study. Clin Infect Dis. 2004;39:1247-9.

78. Xiao JZ, Ma L, Gao J, Yang ZJ, Xing XY, Zhao HC, Jiao JS, Li GW. Glucocorticoid-induced diabetes in severe acute respiratory syndrome: the impact of high dosage and duration of methylprednisolone therapy. Zhonghua Nei Ke Za Zhi. 2004;43:179-82.

79. https://www.recoverytrial.net/news/low-cost-dexamethasone-reduc es-death-by-up-to-one-third-in-hospitalised-patients-with-severe-respi ratory-complications-of-covid-19. Accessed 17 Jul. 2020.

80. Zhou Y, Fu B, Zheng X, Wang D, Zhao C, qi Y, Sun R, Tian Z, Xu X, Wei $H$. Pathogenic T cells and inflammatory monocytes incite inflammatory storm in severe COVID-19 patients. Natl Sci Rev. 2020. https://doi. org/10.1093/nsr/nwaa041.

81. Fu B, Xu X, Wei H. Why tocilizumab could be an effective treatment for severe COVID-19? J Transl Med. 2020;18:164.

82. Bhatraju PK, Ghassemieh BJ, Nichols M, Kim R, Jerome KR, Nalla AK, Greninger AL, Pipavath S, Wurfel MM, Evans L, Kritek PA, West TE, Luks A, Gerbino A, Dale CR, Goldman JD, O'Mahony S, Mikacenic C. Covid-19 in Critically III Patients in the Seattle Region - Case Series. N Engl J Med. 2020;382:2012-22.

83. Buonaguro FM, Puzanov I, Ascierto PA. Anti-IL6R role in treatment of COVID-19-related ARDS. Version 2. J Transl Med. 2020;18:165.

84. Campochiaro C, Della-Torre E, Cavalli G, De Luca G, Ripa M, Boffini N, Tomelleri A, Baldissera E, Rovere-Querini P, Ruggeri A, Monti G, De Cobelli F, Zangrillo A, Tresoldi M, Castagna A, Dagna L; TOCI-RAF Study Group. Efficacy and safety of tocilizumab in severe COVID-19 patients: a single-centre retrospective cohort study. Eur J Intern Med. 2020;76:43-49.

85. Morena V, Milazzo L, Oreni L, Bestetti G, Fossali T, Bassoli C, Torre A, Cossu MV, Minari C, Ballone E, Perotti A, Mileto D, Niero F, Merli S, Foschi A, Vimercati S, Rizzardini G, Sollima S, Bradanini L, Galimberti L, Colombo R, Micheli V, Negri C, Ridolfo AL, Meroni L, Galli M, Antinori S, Corbellino M. Off-label use of tocilizumab for the treatment of SARSCoV-2 pneumonia in Milan. Italy. Eur J Intern Med. 2020;76:36-42.

86. Guaraldi G, Meschiari M, Cozzi-Lepri A, Milic J, Tonelli R, Menozzi M, Franceschini E, Cuomo G, Orlando G, Borghi V, Santoro A, Di Gaetano M, Puzzolante C, Carli F, Bedini A, Corradi L, Fantini R, Castaniere I, Tabbì L, Girardis M, Tedeschi S, Giannella M, Bartoletti M, Pascale R, Dolci G, Brugioni L, Pietrangelo A, Cossarizza A, Pea F, Clini E Salvarani, C, Massari M, Viale PL, Mussini C. Tocilizumab in patients with severe COVID-19: a retrospective cohort study. Lancet Rheumatol. 2020. https://doi. org/10.1016/s2665-9913(20)30173-9.

87. https://www.roche.com/investors/updates/inv-update-2020-07-29.htm Access on 29 July 2020.

88. https://clinicaltrials.gov. Access on 10 August 2020.

89. Montesarchio V, Parella R, lommelli C, et al. Outcomes and biomarker analyses among patients with COVID-19 treated with interleukin 6 (IL-6) receptor antagonist sarilumab at a single institution in Italy. Journal for ImmunoTherapy of Cancer. 2020;8:e001089.

90. Conrozier T, Lohse A, Balblanc JC, et al. Biomarker variation in patients successfully treated with tocilizumab for severe coronavirus disease 2019 (COVID-19): results of a multidisciplinary collaboration. Clin Exp Rheumatol. 2020;38(4):742-7.

91. Cavalli G, De Luca G, Campochiaro C, Della-Torre E, Ripa M, Canetti D, Oltolini C, Castiglioni B, Tassan Din C, Boffini N, Tomelleri A, Farina N, Ruggeri A, Rovere-Querini P, Di Lucca G, Martinenghi S, Scotti R, Tresoldi M, Ciceri F, Landoni G, Zangrillo A, Scarpellini P, Dagna L. Interleukin-1 blockade with high-dose anakinra in patients with COVID-19, acute 
respiratory distress syndrome, and hyperinflammation: a retrospective cohort study. Lancet Rheumatol. 2020;2:e325-31.

92. Cantini F, Niccoli L, Matarrese D, Nicastri E, Stobbione P, Goletti D. Baricitinib therapy in COVID-19: a pilot study on safety and clinical impact. J Infect. 2020;50163-4453(20):30228

93. Du L, He Y, Zhou Y, Liu S, Zheng BJ, Jiang S. The spike protein of SARS-CoV-a target for vaccine and therapeutic development. Nat Rev Microbiol. 2009;7:226-36.

94. Coutard B, Valle C, de Lamballerie X, Canard B, Seidah NG, Decroly E. The spike glycoprotein of the new coronavirus 2019-nCoV contains a furin-like cleavage site absent in CoV of the same clade. Antiviral Res. 2020;176:104742.

95. Li F. Structure, function, and evolution of coronavirus spike proteins. Annu Rev Virol. 2016;3:237-61.

96. Graham RL, Donaldson EF, Baric RS. A decade after SARS: strategies for controlling emerging coronaviruses. Nat Rev Microbiol. 2013;11:836-48.

97. Okba NM, Raj VS, Haagmans BL. Middle East respiratory syndrome coronavirus vaccines: current status and novel approaches. Curr Opin Virol. 2017;23:49-58

98. Bisht H, Roberts A, Vogel L, Subbarao K, Moss B. Neutralizing antibody and protective immunity to SARS coronavirus infection of mice induced by a soluble recombinant polypeptide containing an N-terminal segment of the spike glycoprotein. Virology. 2005;334:160-5.

99. Qi X, Ke B, Feng Q, Yang D, Lian Q, Li Z, Lu L, Ke C, Liu Z, Liao G. Construction and immunogenic studies of a $\mathrm{mFc}$ fusion receptor binding domain (RBD) of spike protein as a subunit vaccine against SARS-CoV-2 infection. Chem Commun (Camb). 2020. https://doi.org/10.1039/d0cc0 $3263 \mathrm{~h}$.

100. Chen WH, Tao X, Agrawal A, Algaissi A, Peng BH, Pollet J, Strych U, Bottazzi ME, Hotez PJ, Lustigman S, Du L, Jiang S, Tseng CK. Yeast-Expressed SARS-CoV Recombinant Receptor-Binding Domain (RBD219-N1) Formulated with Alum Induces Protective Immunity and Reduces Immune Enhancement. Version 3. bioRxiv [Preprint]. 2020:2020.05.15.098079. https://doi.org/10.1101/2020.05.15.098079.

101. Kalita P, Padhi AK, Zhang KYJ, Tripathi T. Design of a peptide-based subunit vaccine against novel coronavirus SARS-CoV-2. Microb Pathog. 2020;145:104236.

102. Yang ZY, Kong WP, Huang Y, Roberts A, Murphy BR, Subbarao K, Nabel GJ. A DNA vaccine induces SARS coronavirus neutralization and protective immunity in mice. Nature. 2004:428(6982):561-4.

103. http://ir.inovio.com/news-releases/news-releases-details/2020/Inovi o-Accelerates-Timeline-for-COVID-19-DNA-Vaccine-INO-4800/defau It.aspx. Accessed 17 Jul. 2020.

104. https://www.inovio.com/dna-medicines-pipeline/. Accessed 17 Jul. 2020

105. https://www.inovio.com/?s=dMAb+. Accessed $17 \mathrm{Jul} .2020$.

106. Zhang C, Maruggi G, Shan H, Li J. Advances in mRNA vaccines for infectious diseases. Front Immunol. 2019;10:594.

107. Pardi N, Hogan MJ, Porter FW, Weissman D. mRNAvaccines - a new era in vaccinology. Nat. Rev. Drug Discov. 2018;17:261-79.

108. https://www.modernatx.com/pipeline. Accessed 17 Jul 2020

109. Stoll HF. Value of convalescent blood and serum in treatment of influenza pneumonia. JAMA. 1919:73:478-83.

110. O'Malley JJ, Hartman FW. Treatment of influenzal pneumonia with plasma of convalescent patients. JAMA. 1919;72:3437.

111. Ross CW, Hund EJ. Transfusion on the desperate pneumonias complicating influenza -preliminary report on the successful use of total immune citrated blood. JAMA. 1918;71:1992-3.

112. McGuire LW, Redden WR. Treatment of influenzal pneumonia by the use of convalescent human serum — preliminary report. JAMA. 1918;71:1311

113. McGuire LW, Redden WR. Treatment of influenzal pneumonia by the use of convalescent human serum. JAMA. 1919;72:709-13.

114. Sanborn GP. The use of the serum of convalescents in the treatment of influenza pneumonia: a summary of the results in a series of one hundred and one cases. Boston Medical and Surgical Journal. 1920;183:171-7.

115. https://www.fda.gov/vaccines-blood-biologics/investigational-newdrug-ind-or-device-exemption-ide-process-cber/recommendations -investigational-covid-19-convalescent-plasma. Accessed 17 Jul 2020
116. Scheid JF, Mouquet $H$, Feldhahn N, Seaman MS, Velinzon K, Pietzsch J, Ott RG, Anthony RM, Zebroski H, Hurley A, Phogat A, Chakrabarti B, Li Y, Connors M, Pereyra F, Walker BD, Wardemann H, Ho D, Wyatt RT, Mascola JR, Ravetch JV, Nussenzweig MC. Broad diversity of neutralizing antibodies isolated from memory B cells in HIV-infected individuals. Nature. 2009;458:636-40.

117. Corti D, Misasi J, Mulangu S, Stanley DA, Kanekiyo M, Wollen S, Ploquin A, Doria-Rose NA, Staupe RP, Bailey M, Shi W, Choe M, Marcus H, Thompson EA, Cagigi A, Silacci C, Fernandez-Rodriguez B, Perez L, Sallusto F, Vanzetta F, Agatic G, Cameroni E, Kisalu N, Gordon I, Ledgerwood JE, Mascola JR, Graham BS, Muyembe-Tamfun JJ, Trefry JC, Lanzavecchia A, Sullivan NJ. Protective monotherapy against lethal Ebola virus infection by a potently neutralizing antibody. Science. 2016:351:1339-42.

118. Wang L, Shi W, Chappell JD, Joyce MG, Zhang Y, Kanekiyo M, Becker MM, van Doremalen N, Fischer R, Wang N, Corbett KS, Choe M, Mason RD, Van Galen JG, Zhou T, Saunders KO, Tatti KM, Haynes LM, Kwong PD, Modjarrad K, Kong WP, McLellan JS, Denison MR, Munster VJ, Mascola JR, Graham BS. Importance of Neutralizing Monoclonal Antibodies Targeting Multiple Antigenic Sites on the Middle East Respiratory Syndrome Coronavirus Spike Glycoprotein To Avoid Neutralization Escape. J Virol. 2018;92:e02002-17.

119. Xu J, Jia W, Wang P, Zhang S, Shi X, Wang X, Zhang L. Antibodies and vaccines against Middle East respiratory syndrome coronavirus. Emerg Microbes Infect. 2019:8:841-56.

120. Caskey M, Schoofs T, Gruell H, Settler A, Karagounis T, Kreider EF, Murrell B, Pfeifer N, Nogueira L, Oliveira TY, Learn GH, Cohen YZ, Lehmann C, Gillor D, Shimeliovich I, Unson-O'Brien C, Weiland D, Robles A, Kümmerle T, Wyen C, Levin R, Witmer-Pack M, Eren K, Ignacio C, Kiss S, West AP Jr, Mouquet H, Zingman BS, Gulick RM, Keler T, Bjorkman PJ, Seaman MS, Hahn BH, Fätkenheuer G, Schlesinger SJ, Nussenzweig MC, Klein F. Antibody 10-1074 suppresses viremia in HIV-1-infected individuals. Nat Med. 2017;23:185-91.

121. Wrapp D, Wang N, Corbett KS, Goldsmith JA, Hsieh CL, Abiona O, Graham BS, McLellan JS. Cryo-EM structure of the 2019-nCoV spike in the prefusion conformation. Science. 2020;367:1260-3.

122. Lu G, Wang Q, Gao GF. Bat-to-human: spike features determining 'host jump' of coronaviruses SARS-CoV, MERS-CoV, and beyond. Trends Microbiol. 2015;23:468-78.

123. Cao Y, Su B, Guo X, Sun W, Deng Y, Bao L, Zhu Q, Zhang X, Zheng Y, Geng C, Chai X, He R, Li X, Lv Q, Zhu H, Deng W, Xu Y, Wang Y, Qiao L, Tan Y, Song L, Wang G, Du X, Gao N, Liu J, Xiao J, Su XD, Du Z, Feng $Y$, Qin C, Qin C, Jin R, Xie XS. Potent Neutralizing Antibodies against SARS-CoV-2 Identified by High-Throughput Single-Cell Sequencing of Convalescent Patients'B Cells. Cell. 2020;182(73-84):e16.

124. Wu Y, Wang F, Shen C, Peng W, Li D, Zhao C, Li Z, Li S, Bi Y, Yang Y, Gong Y, Xiao H, Fan Z, Tan S, Wu G, Tan W, Lu X, Fan C, Wang Q, Liu Y, Zhang C, Qi J, Gao GF, Gao F, Liu L. A noncompeting pair of human neutralizing antibodies block COVID-19 virus binding to its receptor ACE2. Science. 2020:368:1274-8.

125. Shi R, Shan C, Duan X, Chen Z, Liu P, Song J, Song T, Bi X, Han C, Wu L, Gao G, Hu X, Zhang Y, Tong Z, Huang W, Liu WJ, Wu G, Zhang B, Wang L, Qi J, Feng H, Wang FS, Wang Q, Gao GF, Yuan Z, Yan J. A human neutralizing antibody targets the receptor-binding site of SARS-CoV-2. Nature. 2020. https://doi.org/10.1038/s41586-020-2381-y.

126. https://clinicaltrials.gov/ct2/show/study/NCT04411628?term=nct04 411628\&draw $=2 \&$ rank=1. Accessed $17 \mathrm{Jul} 2020$.

127. Chen P, Nirula A, Heller B, Gottlieb RL, Boscia J, Morris J, Huhn G, Cardona J, Mocherla B, Stosor V, Shawa I, Adams AC, Van Naarden J, Custer KL, Shen L, Durante M, Oakley G, Schade AE, Sabo J, Patel DR, Klekotka P, Skovronsky DM; BLAZE-1 Investigators. SARS-CoV-2 Neutralizing Antibody LY-CoV555 in Outpatients with Covid-19. N Engl J Med. 2020 Oct 28:NEJMoa2029849.

128. Chowell G, Echevarría-Zuno S, Viboud C, Simonsen L, Tamerius J, Miller MA, Borja-Aburto VH. Characterizing the epidemiology of the 2009 influenza A/H1N1 pandemic in Mexico. PLoS Med. 2011;8:e1000436.

129. MacDougall H. Toronto's health department in action: influenza in 1918 and SARS in 2003. J Hist Med Allied Sci. 2007;62:56-89.

130. Chu DK, AkI EA, Duda S, Solo K, Yaacoub S, Schünemann HJ; COVID-19 Systematic Urgent Review Group Effort (SURGE) study authors. Physical distancing, face masks, and eye protection to prevent person-to-person 
transmission of SARS-CoV-2 and COVID-19: a systematic review and meta-analysis. Lancet. 2020;395:1973-1987.

131. Larson EL, Cohen B, Baxter KA. Analysis of alcohol-based hand sanitizer delivery systems: efficacy of foam, gel, and wipes against influenza A (H1N1) virus on hands. Am J Infect Control. 2012;40:806-9.

132. Suess T, Remschmidt C, Schink SB, Schweiger B, Nitsche A, Schroeder K, Doellinger J, Milde J, Haas W, Koehler I, Krause G, Buchholz U. The role of facemasks and hand hygiene in the prevention of influenza transmission in households: results from a cluster randomised trial; Berlin, Germany, 2009-2011. BMC Infect Dis. 2012;12:26.

133. Wong VW, Cowling BJ, Aiello AE. Hand hygiene and risk of influenza virus infections in the community: a systematic review and meta-analysis. Epidemiol Infect. 2014;142:922-32.

134. He D, Dushoff J, Day T, Ma J, Earn DJ. Inferring the causes of the three waves of the 1918 influenza pandemic in England and Wales. Proc Biol Sci. 2013;280:20131345.

135. de Sousa E, Ligeiro D, Lérias JR, Zhang C, Agrati C, Osman M, El-Kafrawy SA, Azhar El, Ippolito G, Wang FS, Zumla A, Maeurer M. Mortality in COVID-19 disease patients: correlating the association of major histocompatibility complex (MHC) with severe acute respiratory syndrome 2 (SARS-CoV-2) variants. Int J Infect Dis. 2020;98:454-9.

136. COCONEL Group. A future vaccination campaign against COVID19 at risk of vaccine hesitancy and politicisation. Lancet Infect Dis. 2020;20:769-770.

137. Kaur SP, Gupta V. COVID-19 Vaccine: a comprehensive status report. Virus Res. 2020;288:198114.

138. Tregoning JS, Brown ES, Cheeseman HM, Flight KE, Higham SL, Lemm NM, Pierce BF, Stirling DC, Wang Z, Pollock KM. Vaccines for COVID-19. Clin Exp Immunol. 2020;202:162-92.

139. Costa L, Tasso M, Scotti N, Mostacciuolo E, Girolimetto N, Foglia F, Del Puente A, Scarpa R, Caso F. Telerheumatology in COVID-19 era: a study from a psoriatic arthritis cohort. Ann Rheum Dis. 2020:annrheumdis-2020-217806. https://doi.org/10.1136/annrheumdis-2020-217806.

140. Caso F, Del Puente A, Girolimetto N, Tasso M, Caso C, Scarpa R, Costa L. Improving telemedicine and in-person management of rheumatic and autoimmune diseases, during and after COVID-19 pandemic outbreak. Definite need for more Rheumatologists. Response to: 'Can telerheumatology improve rheumatic and musculoskeletal disease service delivery in sub-Saharan Africa?' by Akpabio et al. Ann Rheum Dis. 2020:annrheumdis-2020-218472. https://doi.org/10.1136/annrheumdi s-2020-218472.

141. Bavli I, Sutton B, Galea S. Harms of public health interventions against covid-19 must not be ignored. BMJ. 2020;371:m4074.

142. Ma X, Vervoort D. Critical care capacity during the COVID-19 pandemic: global availability of intensive care beds. J Crit Care. 2020;58:96-7.

143. White DB, Lo B. A Framework for Rationing Ventilators and Critical Care Beds During the COVID-19 Pandemic. JAMA. 2020;323:1773-4.

144. Meares HD, Jones MP. When a system breaks: queueing theory model of intensive care bed needs during the COVID-19 pandemic. Med J Aust. 2020;212:470-1.

145. Litton E, Bucci T, Chavan S, Ho YY, Holley A, Howard G, Huckson S, Kwong P, Millar J, Nguyen N, Secombe P, Ziegenfuss M, Pilcher D. Surge capacity of intensive care units in case of acute increase in demand caused by COVID-19 in Australia. Med J Aust. 2020;212:463-7.

\section{Publisher's Note}

Springer Nature remains neutral with regard to jurisdictional claims in published maps and institutional affiliations.
Ready to submit your research? Choose BMC and benefit from:

- fast, convenient online submission

- thorough peer review by experienced researchers in your field

- rapid publication on acceptance

- support for research data, including large and complex data types

- gold Open Access which fosters wider collaboration and increased citations

- maximum visibility for your research: over 100M website views per year

At BMC, research is always in progress.

Learn more biomedcentral.com/submissions 